\title{
Co-detection of SARS-CoV-2 with Secondary Respiratory Pathogen Infections
}

J Gen Intern Med 36(4):1159-60

DOI: $10.1007 / \mathrm{s} 11606-020-06471-0$

(C) Society of General Internal Medicine 2021

\section{INTRODUCTION}

More than ten million US residents have been diagnosed with the novel coronavirus (SARS-CoV-2) that causes COVID-19. Testing for concomitant viral respiratory pathogens was initially recommended by the Centers for Disease Control and Prevention (CDC) prior widespread testing for COVID-19. Early reports of coinfection rates with other respiratory pathogens with SARS-CoV-2 varied widely between 0 and $21 \%$ and are limited by small sample sizes. ${ }^{1-3}$ Uncertainty remains in understanding coinfection rates in patients with suspected COVID-19. We report on the presence of viral co-detection between SARS-CoV-2 and other respiratory pathogens in patients presenting to a tertiary care facility in the southeastern US with a moderate caseload of SARS-CoV-2.

\section{METHODS}

We conducted a retrospective analysis of patients presenting to Vanderbilt University Medical Center (VUMC) between March 9, 2020, and October 2, 2020. During this time, Davidson County had a moderate disease burden of COVID-19 with a median of $13.9(11.2,24.5)$ daily new cases per 100,000 residents. Davidson County began a stay-at-home order on March 23, 2020, and began to gradually reopen May 11, 2020. Subjects were included if they were tested for SARS-CoV-2 with reverse transcriptase polymerase chain reaction (RTPCR) and were also tested with a multiplex RT-PCR respiratory pathogen panel (influenza A and B, Adenovirus, Bordetella parapertussis, Bordetella pertussis, Chlamydia pneumoniae, coronavirus 229E, HKU1, NL63, OC43, Metapneumovirus, Parainfluenza, Mycoplasma pneumoniae, RSV, and Rhinovirus/enterovirus) on the same day of the SARS-CoV-2 test. Only the first overall test for a subject for SARS-CoV-2 was included. Asymptomatic individuals identified by treating clinicians through the electronic health record at the time of SARS-CoV-2 testing were excluded. Analysis is

Received September 4, 2020

Accepted December 14, 2020

Published online January 27, 2021 primarily descriptive in nature. This study was approved by the VUMC institutional review board as exempt.

\section{RESULTS}

Overall, there were 145,198 tests for SARS-CoV-2 for 100,121 unique individuals within the study period. There were 3105 symptomatic subjects tested for SARS-CoV-2 with concomitant respiratory pathogen panel testing during the study period. The cohort is described in Table 1. Among those tested for both SARS-CoV-2 and other respiratory pathogens, $288(9.3 \%)$ subjects tested positive for SARS-CoV-2 and among these, $14(4.9 \%)$ tested positive for a second respiratory pathogen. Those with a co-detection of SARS-CoV-2 and another respiratory pathogen were younger than those who had an isolated detection of SARS-CoV-2 (mean of $14.0 \mathrm{vs.}$ 42.4 years). Among subjects who tested negative for SARSCoV-2, Rhinovirus/enterovirus ( $60.9 \%$ of all SARS-CoV-2 negative patients) was the most common respiratory pathogen whereas both Adenovirus and Rhinovirus/enterovirus (42.9\% of all SARS-CoV-2 positive patients each) were the most common respiratory pathogens among patients who tested positive for SARS-CoV-2 (Table 2).

\section{DISCUSSION}

We report the respiratory co-detection rate in a single, tertiary care center in the USA with a moderate caseload of SARS$\mathrm{CoV}-2$. This is the largest sample of co-detection of SARS$\mathrm{CoV}-2$ and other respiratory pathogens encompassing a longer duration and later phases of the pandemic. Compared with prior reports in the USA of $1.9 \%{ }^{5}$ and $20.7 \%{ }^{1}$ we found that the respiratory pathogen co-detection rate $(4.9 \%)$ in our sample is low. This suggests that the utility of simultaneous respiratory pathogen testing may be limited in the setting of a positive SARS-CoV-2 test, particularly in adults. Potential reasons for lower rates of co-detection include seasonality and background rates of other viral respiratory pathogens which are expected to be higher in winter months, yet not included in our study timeframe. However, our study includes a longer timeframe and more patients with SARS-CoV-2 than previously published along with an extended temporal window that includes time periods before, during, and after the most stringent social distancing recommendations in Tennessee. Also, the onset of the pandemic changed human behavior to increase 
Table 1 Demographics of Patients Included in the Analysis by SARS-CoV-2 and Viral Respiratory Pathogen Status

\begin{tabular}{|c|c|c|c|c|c|c|c|c|c|c|c|c|}
\hline \multirow{2}{*}{$\begin{array}{l}\text { Variable, } N, \\
\%\end{array}$} & \multicolumn{6}{|c|}{ Negative $(n=2817)$} & \multicolumn{6}{|l|}{ Positive $(n=288)$} \\
\hline & $\begin{array}{l}\text { Positive for oth } \\
\text { respiratory } \\
\text { pathogen }\end{array}$ & & $\%$ & $\begin{array}{l}\text { Negative for ot } \\
\text { respiratory } \\
\text { pathogen }\end{array}$ & & $\%$ & $\begin{array}{l}\text { Positive for other } \\
\text { respiratory } \\
\text { pathogen }\end{array}$ & & $\%$ & $\begin{array}{l}\text { Negative for otl } \\
\text { respiratory } \\
\text { pathogen }\end{array}$ & her & $\%$ \\
\hline \multirow{2}{*}{$\begin{array}{l}\text { Patients } \\
\text { Age, mean } \\
\text { (range) } \\
\text { Female }\end{array}$} & $20.1(0-94)$ & 686 & $24.4 \%$ & $37.5(0-104)$ & 2131 & $75.6 \%$ & $14.0(0-58)$ & 14 & $4.9 \%$ & $42.4(0-93)$ & 274 & $95.1 \%$ \\
\hline & & 350 & $51.0 \%$ & & 1132 & $53.1 \%$ & & 6 & $42.9 \%$ & & 121 & $44.2 \%$ \\
\hline
\end{tabular}

Table 2 Distribution of Viral Respiratory Pathogens by SARS-CoV2 Status

\begin{tabular}{|c|c|c|c|c|}
\hline \multirow[t]{2}{*}{ Pathogen } & \multicolumn{2}{|c|}{$\begin{array}{l}\text { SARS-CoV-2 } \\
\text { negative }(n= \\
686)\end{array}$} & \multicolumn{2}{|c|}{$\begin{array}{l}\text { SARS-CoV-2 } \\
\text { positive }(n= \\
\text { 14) }\end{array}$} \\
\hline & $N$ & $\%$ & $N$ & $\%$ \\
\hline \multicolumn{5}{|l|}{ Influenza } \\
\hline A & 46 & $6.7 \%$ & 0 & $0 \%$ \\
\hline B & 12 & $1.7 \%$ & 0 & $0 \%$ \\
\hline Adenovirus & 100 & $14.6 \%$ & 6 & $42.9 \%$ \\
\hline Bordetella parapertussis & 2 & $0.3 \%$ & 1 & $7.1 \%$ \\
\hline Bordetella pertussis & 2 & $0.3 \%$ & 0 & $0 \%$ \\
\hline Chlamydia pneumoniae & 6 & $0.9 \%$ & 0 & $0 \%$ \\
\hline \multicolumn{5}{|l|}{ Other Coronaviridae } \\
\hline $\begin{array}{l}229 \mathrm{E} \\
\text { HKU1 }\end{array}$ & 4 & $0.6 \%$ & 0 & $\begin{array}{l}0 \% \\
0 \%\end{array}$ \\
\hline HKU1 & 19 & $2.8 \%$ & 0 & $0 \%$ \\
\hline NL63 & 51 & $7.4 \%$ & 0 & $0 \%$ \\
\hline OC43 & 8 & $1.2 \%$ & 0 & $0 \%$ \\
\hline Metapneumovirus & 60 & $8.7 \%$ & 0 & $0 \%$ \\
\hline Parainfluenza & 12 & $1.7 \%$ & 0 & $0 \%$ \\
\hline Myсорlasma pneuтопiae & 6 & $0.9 \%$ & 0 & $0 \%$ \\
\hline RSV & 20 & $2.9 \%$ & 1 & $7.1 \%$ \\
\hline Rhinovirus/enterovirus & 418 & $60.9 \%$ & 6 & $42.9 \%$ \\
\hline
\end{tabular}

hand hygiene ${ }^{6}$ and the use of mitigation measures (e.g., mask wearing) all of which decrease transmission. ${ }^{7}$

Our findings are limited by the non-systematic testing for respiratory pathogens which was determined by the treating clinician and subsequently subject to bias. Further, respiratory coinfection in the setting of lower COVID-19 disease prevalence may not be generalizable to larger populations with higher prevalence rates. Finally, test characteristics for the RT-PCR were not available due to the vast heterogeneity in testing reagents due to the supply chain limitations affecting US hospitals during this early phase of the pandemic.

Clifford L. Freeman, $M D^{1}$

Nathaniel M. Miller, $M D^{1}$

Lisa Bastarache, $\mathrm{MS}^{2}$

Josh Peterson, $M D, M P H^{2}$

Wesley H. Self, MD, MPH ${ }^{1}$

Tyler W. Barrett, MD, MSCI ${ }^{1}$

Michael J. Ward, $\mathrm{MD}, \mathrm{Ph} \mathrm{D}^{1,2,3}$
${ }^{1}$ Department of Emergency Medicine, Vanderbilt University Medical Center,

Nashville, TN, USA

${ }^{2}$ Department of Biomedical Informatics, Vanderbilt University Medical Center,

Nashville, TN, USA

${ }^{3}$ VA Tennessee Valley Healthcare System,

Nashville, TN, USA

Corresponding Author: Michael J. Ward, MD, PhD; VA Tennessee Valley Healthcare System, Nashwille, TN, USA (e-mail: michael.j.ward@vumc.org).

Compliance with Ethical Standards:

Conflict of Interest: The authors declare that they do not have a conflict of interest.

\section{REFERENCES}

1. Kim D, Guinn J, Pinsky B, Shah NH, Brown I. Rates of co-infection between SARS-CoV-2 and other respiratory pathogens. JAMA. 2020;323:2085-6.

2. Chen N, Zhou M, Dong $\mathbf{X}$, et al. Epidemiological and clinical characteristics of 99 cases of 2019 novel coronavirus pneumonia in Wuhan, China: a descriptive study. Lancet. 2020;395(10223):507-513.

3. Calcagno A, Ghisetti V, Burdino E, et al. Coinfection with other respiratory pathogens in COVID-19 patients. Clin Microbiol Infect. 2020;S1 198-743X(20):30494-8. https://doi.org/10.1016/j.cmi.2020.08. 012. Online ahead of print.

4. Harvard Global Health Initiaitve COVID-19 risk levels by county. https:// globalepidemicsorg/key-metrics-for-covid-suppression/.Acessed September 22, 2020.

5. Castillo EM, Coyne CJ, Brennan JJ, Tomaszewski CA. Rates of coinfection with other respiratory pathogens in patients positive for coronavirus disease 2019 (COVID-19). J Am Coll Emerg Physicians Open. 2020;1(4):592-596. https://doi.org/10.1002/emp2.12172. Online ahead of print.

6. Moore LD, Robbins G, Quinn J, Arbogast JW. The impact of COVID-19 pandemic on hand hygiene performance in hospitals. Am J Infect Control. 2021;49:30-3.

7. Kanu FA, Smith EE, Offutt-Powell T, Hong R, Dinh T, Pevzner E. Declines in SARS-CoV-2 transmission, hospitalizations, and mortality after implementation of mitigation measures- Delaware, March-June 2020. MMWR CDC Surveill Summ. 2020;69:1691-4.

Publisher's Note: Springer Nature remains neutral with regard to jurisdictional claims in published maps and institutional affiliations. 